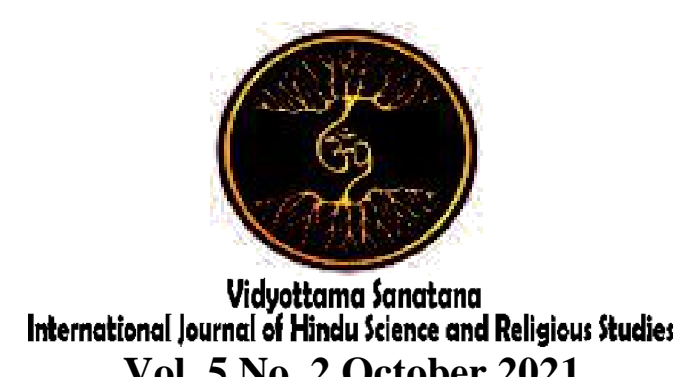

Vol. 5 No. 2 October 2021

\title{
THE COMMUNITY-BASED ECOTOURISM DEVELOPMENT ON "TAMAN BEJI GRIYA" IN PUNGGUL VILLAGE, ABIAN SEMAL, BADUNG
}

\author{
By: \\ A.A. Inten Mayuni', A.A. Rai Sitalaksmi², Ni Made Suwendri ${ }^{3}$ \\ 1,2,3 Faculty of Letters, Warmadewa University, Denpasar. \\ E-mail: ${ }^{1}$ intenmayuni59@gmail.com, ${ }^{2}$ sitalaksmi08@gmail.com, ${ }^{3}$ suwendri63@gmail.com
}

Received: June 11, 2021

Accepted: June 14, 2021

Published: October 31, 2021

\begin{abstract}
The community-based ecotourism (CBET) is a new paradigm of tourism to encourage the preservation of nature and culture, as well as improve the economy of local people. The development of CBET "Taman Beji Griya" in Punggul Village which is managed by the extended family community, "Griya Gede Manuaba Punggul", is the main focus of this study. This CBET combines natural attractions such as waterfalls and caves with malukat and tirtayatra rituals, without changing its socio-religious function. Through a management strategy and a SWOT analysis approach, the development pattern and the potential and constraints of this CBET can be identified. This study found that the development pattern of CBET "Taman Beji Griya" includes the environment scanning, formulation strategy, implementation strategy, evaluation and control. The potential and constraints for the development of CBET "Taman Beji Griya" include internal and external factors. The internal potential includes land ownership status, management competence, and family support. Its external potential includes positive responses from tourists, community support, and the influence of social media. Internal constraints include limited financial capital, human resources, and management. Externally, the constraints include government regulations, relationships with traditional institutions and local agencies, as well as uncertain sources of income.
\end{abstract}

Keywords: ecotourism, community, development. 


\section{INTRODUCTION}

The Covid-19 pandemic that has hit the world since the end of 2019 has changes the global order and has had a significant impact on the Bali tourism industry. In August 2020, the number of foreign tourist arrivals to Bali is fell sharply by 100 percent, when compared to the same month in

(https://bali.bps.go.id/subject/16/pariwisata .html, accessed January 2, 2021). The decline in Bali tourism due to unpredictable global conditions, is also reminiscent of the Bali Bombings I and II. This incident prompted several countries to implement a policy of restricting tourist travel to Bali to their citizens so that the number of foreign tourist arrivals fell sharply. This means that the development of mass tourism in Bali is highly dependent on the conduciveness of the region and the travel policies of foreign countries. If one or both of these conditions are not met, the large number of foreign tourist visits that are the main drivers of mass tourism will be difficult to realize.

In the sociocultural perspective, the development of the mass tourism industry has the potential to present a paradoxical situation for the Balinese people. On the one hand, tourism is the backbone of the Bali's economy. But on the other hand, it also often considered as the cause of environmental damage, conversion of agricultural land, cultural-religious commodification, and social conflict (Ace, 2017:7). Related to that, Picard (2006) states that the tourism industry offers a dilemmatic choice to the Balinese, especially to maintain their culture in strengthening of the touristic culture. Picard (2006:247-248), even emphasized that, 'what the Balinese pay more attention to now is how to use their culture for tourism, not assessing the impact of tourism on their culture'.

The dependence of mass tourism on the global situation and the resulting sociocultural paradox suggests the importance of alternative tourism that can overcome these weaknesses. One of the tourism paradigms that is now starting to be developed in several areas is ecotourism. According to Arida (2017:15), the idea of ecotourism emerged from criticism of the paradigm of mass tourism which tends to exploit the environment and natural resources. The ecotourism paradigm has also been adapted by the government with the issuance of the Minister of Home Affairs Regulation No. 33 of 2009 about Guidelines for Regional Ecotourism Development. This regulation defines ecotourism as nature tourism activities in responsible areas by taking into account elements of education, mutual understanding, supporting efforts to conserve natural resource, and increasing local community income. This concept has a meaning in line with the idea of sustainable tourism, namely the management and empowerment of socioeconomic resources that can be fulfilled by maintaining cultural integrity, ecological elements basic, biodiversity, and other supporting elements (Satria, 2009:37). Sustainable tourism which is more environmentally and socially friendly, can overcome the fundamental weakness of mass tourism which tends to be exploitative. Through the development of ecotourism, the existence and function of tourist objects are maintained, and the community gains added economic value from these objects.

One of the phenomena of community-based ecotourism (CBET) development in Bali that is used as the object of this research is "Taman Beji Griya" in Punggul Village, Abiansemal, Badung Regency. Preliminary studies show that Taman Beji Griya is managed by extended family of "Griya Gede Manuaba Punggul". This ecotourism object combines natural resources, that is waterfalls and the "Kereb Langit" cave with Hindu religious traditions, namely tirtayatra and malukat. The development of the function of Beji Merajan Griya into a tourist attraction does not change its socio-religious function, and even has a positive impact on environmental conservation and provides 
added economic value. Contribution to the environment is marked by the application of rules to visitors so as not to carry out activities that have the potential to damage the sustainability and natural beauty around the area. Meanwhile, the economic value of the expansion of the beji function is obtained from punia (sincere donations) from visitors and rental of some of the needs of tourists.

However, the expansion of the economic function of "Taman Beji Griya" also encourages the cultural-religious commodification with sacred value. In addition, this ecotourism is only managed by the extended family of "Griya Gede Manuaba Punggul", without involving the larger community, such as banjar (subvillage), official villages, and traditional institution that cover the area. Based on Dahrendorf's conflict theory (in Ritzer, 2003:23), the management of this ecotourism saves the latent potential of social conflict in Punggul Village due to the unequal distribution of position and authority, especially to access its economic resources. This means that the development of CBET "Taman Beji Griya" still leaves paradoxical sociocultural problems which can arise at any time. On the one hand, this ecotourism has the potential to be developed and make a positive contribution to the surrounding community, but on the other hand, it has the potential to trigger conflicts between community due to fighting over resources.

Based on that's phenomenon, the research was conducted to examine the development strategies of CBET "Taman Beji Griya" with SWOT analysis approach (strengths, weakness, opportunities, and threats). Through SWOT analysis, future productive development strategies can be explored. The development strategy is also systematically reviewed with a management strategy. This research focused on answering the following problem formulation, (1) How is the development pattern of CBET "Taman Beji Griya"? and (2) What are the potentials and obstacles in developing of CBET "Taman Beji Griya"? The main objective of this study is to find a ideal pattern of ecotourism development in Bali.

\section{METHODS}

This study was designed within the framework of a qualitative research methodology with a SWOT analysis approach. SWOT analysis consist of strength, weakness, opportunity, and threats is mainly carried out by evaluating internal factors (Internal Factor Evaluation/IFE) and external factors (External Factor Evaluation/EFE) to explore including (David, 1993). This research data was collected from the research field covering the management process and ecotourism activities in CBET "Taman Beji Griya". Data collected by observation, interview, document study, and focus group discussion. This study applies a qualitativeinterpretive data analysis technique which according to Bogdan and Biklen (1984) is carried out during the research. In its application, the data analysis technique is carried out by following the three stages as proposed by Miles and Huberman (1992), namely data reduction, data display, and verification. Furthermore, the results of data analysis are used to formulate an evaluation of external and internal factors (IFE/EFE) through the SWOT analysis.

\section{RESULT AND DISCUSSION}

Ecotourism development strategy can be referred to Minister of Home Affairs Regulation No. 33 of 2009 which in General Provisions Article (1) Point (2) which states that ecotourism development is an activity of planning, utilizing, and controlling ecotourism. Then it is further explained in Article (3) that the principles of ecotourism development include:

a. the suitability between the types and characteristics of ecotourism;

b. conservation, namely protecting, preserving, and sustainably utilizing natural resources used for ecotourism; 
c. economical, namely providing benefits to the local community and being a driver of economic development in the region as well as ensuring ecotourism business can be sustainable;

d. education, which contains elements of education to change one's perception so that they have care, responsibility, and commitment to environmental and cultural preservation;

e. provide satisfaction and experience to visitors; and,

f. community participation, namely community participation in the planning, utilization, and control of ecotourism by respecting the sociocultural and religious values of the community around the area; and,

g. accommodate local wisdom.

The ecotourism development strategy must be carried out through three stages, namely planning, utilization, and control of ecotourism, so that tourism management determines the success of the strategies established and implemented. Based on this understanding, strategic management theory is used as a reference to analyze the ecotourism development strategy of Taman Beji Griya. According to Wheelen and Hunger (2003), strategic management includes the following four basic elements, i.e., (a) environmental scanning is carried out on the external environment to observe opportunities and threats, as well as the internal environment to see strengths and weaknesses; (b) strategy formulation is the development of a long-term plan to determine effective management based on the opportunities and threats of the external environment that are assessed based on internal strengths and weaknesses. Strategy formulation includes determining the mission, goals to be achieved, developing strategies, and establishing policy guidelines; (c) strategy implementation is the strategic management process and its policies in action through the development of programs, budgets and procedures. The process includes a change in the overall culture, structure and management system of the organization as a whole; and (d) evaluation and control is the process of monitoring activities and their results by comparing the actual performance with the expected performance. In addition, evaluation and control can accurately show the weaknesses of the previous strategy implementation so that strategy improvements can be made. This theory can be revealed the patterns, potentials and constraints of ecotourism development at "Taman Beji Griya".

\section{a. Development Pattern}

CBET "Taman Beji Griya" is located in Punggul Village, Abiansemal, Badung Regency. This place was originally a beji (a place to ask for holy water) which is also used by Hindus in Punggul Village for various yajna (ritual) purposes. This function still survives until now, although it has been developed into an ecotourism object. The ecotourism development pattern of "Taman Beji Griya" can be analyzed based on four basic elements of strategic management which include environmental scanning, strategy implementation, strategy implementation, and also evaluation and control (Wheelen and Hunger, 2003). The four strategies have been carried out since the manager's idea to develop ecotourism objects and continues to this day. This confirms that the development pattern of CBET "Taman Beji Griya" is carried out in a sustainable manner.

The environmental scanning began when the managers (Ida Pedanda Gde Buruan Manuaba and Ida Bagus Eka Giriputra) discovered the potential of the place to be developed into an ecotourism object. This idea is not only based on rational thought, but also through supernatural clues (pawisik). Considering at that time, the waterfall which was the advantage of tourist attraction had not yet appeared because it was still covered with bushes. Yeh (water) and abing (cliff) are the 
two keywords heard in the pawisik. This pawisik was obtained in early 2017 and only found the answer in March. After that, the management began to clear the bushes on the cliff that blocked the waterfall. Finally, the waterfall was seen and looked very beautiful. The beauty of this waterfall is seen by the manager as a potential to be developed into ecotourism.

The formulation strategy begins with determining the long-term goals of the ecotourism development, namely building ecotourism that can provide added economic value without losing its religious function as a beji. Because this beji belongs to Griya Gede Manuaba Punggul, its development was carried out by involving the extended family of the griya. Even though, the management also wants to involve the sisya griya (people who are socially bound to the griya in a patronclient relationship) as workers. So, in the long term, the development of ecotourism can create jobs. Its mean that, the long-term goal of this ecotourism development is to increase economic value, maintain religious and environmental functions, and create jobs for the surrounding community.

The strategy implementation began in April 2017 by cleaning around ecotourism objects. Followed by providing parking space and improving road access to the location. The palinggih (Hindu religious sacred buildings) that had existed before were beautified by adding some ornaments. Eventually, this ecotourism object was officially opened in October 2017 which was preceded by the mlaspas ceremony. To promote this ecotourism object, the manager uses more social media, especially Facebook and Instagram. However, promotions also take place indirectly from visitors who upload selfies at the venue on social media. Since then, this ecotourism has been increasingly visited by tourists, both local and foreign. Some of them enjoy its natural beauty, but others also come to malukat (Hindu rituals to purify oneself).

Evaluation and control are continuously carried out by the management, both in terms of facilities, comfort, and economic benefits. From the results of this evaluation, the manager continues to improve the facilities, such as providing locker rooms, toilets, coffee shops, and adding several other facilities to enhance the appearance around the melukat area. For the convenience of visitors, the manager also provides senteng (scarf to tie the waist), kamen (sheet of cloth to cover the lower body), banten (offerings), and guides for tourists in carrying out the melukat ritual. To increase the economic value, the management rents out senteng, kamen, locker rooms, and sells offerings with a price range of 10 thousand rupiahs for each item. However, visitors are not charged a special rate to enjoy these objects.

\section{b. The Potential and Constraints in Development}

The potential and constraints of ecotourism development in Taman Beji Griya can be divided into internal and external. In the SWOT analysis, internal potentials and constraints are assessed by evaluating internal factors (IFE), especially those related to management. On the other hand, external potentials and constraints are obtained through evaluation of external factors (EFE) that influence the development of the ecotourism object. Based on the analysis model, the potential and constraints for the development of Taman Beji Griya in Punggul Village can be explained as follows.

First, the internal potentials of ecotourism development ini "Taman Beji Griya" is the legal status of land ownership. This potential provides legal certainty to the manager (the extended family of Griya Gede Manuaba Punggul) to develop the ecotourism object. Second, the internal potential possessed is the competence of the manager. In this case, Ida Bagus Eka Giriartha as the manager has a tourism education background and has worked in the tourism sector for several years so he has a lot of experience in managing tourist objects. Third, is the full support from the 
extended family of Griya Gede Manuaba Punggul. The extended family has given approval and authority to Ida Bagus Eka Giriartha to manage the ecotourism object by involving several other family members.

This internal potential is also supported by external potential, including positive responses from visitors, community support, and the influence of social media. Some visitors say that besides being beautiful, this place also exudes a positive spiritual aura. This ecotourism also gets support from the surrounding community because in addition to providing an economic impact, ritual activities in beji become easier to do because of better road access and a more comfortable place. Another external factor that supports the development of the CBET "Taman Beji Griya" is the impact of social media. Tourists who upload photos on social media provide free promotions so that many people are interested in visiting.

In addition to these various potentials, there are also several obstacles in its development which can be distinguished into internal and external constraints. Internal constraints faced include limited financial capital, human resources, and management. Limited financial capital is the first constraints because all funding needs in ecotourism development of "Taman Beji Griya" are borne by the manager. This limited capital makes the development of ecotourism run step by step. Human resources are also the next internal obstacle, especially the ability of employees to speak English. Considering that the employees are prioritized by the sisya griya and the surrounding community who do not always have competence in the field of tourism services. And finally, the obstacle faced is the traditional management model in the absence of a clear structure and work mechanism. All responsibility is entirely in the hands of Ida Bagus Eka Giriputra as the manager.

Externally, the constraints faced include government regulations, relationships with traditional institutions and local agencies, as well as uncertain sources of income. In the realm of government regulation, the main obstacle faced is the obligation to pay taxes if ecotourism is officially managed and attracts tariffs to tourists. Even though the management wants to maintain the social, religious, and environmental functions of the ecotourism object by not charging visitors. Relationships with traditional villages and local government offices are also an obstacle that even has a potential conflict of interest because until now there has been no written agreement regarding the involvement of villages in the management of ecotourism. The two sides seemed to be waiting for each other and there was no initiative to open communication first. The last external constraint is the uncertain sources of income, either due to fluctuations in the number of visitors or because there is no set tariff. The management only relies on locker room, senteng, and kamen rentals, also punia from visitors.

\section{CONCLUSION}

This study found that the development pattern of CBET "Taman Beji Griya" includes the environment scanning which started in early 2017' through rational consideration and pawisik; formulation strategy by involving the extended family of Griya Gede Manuaba Punggul; implementation strategy by combining ecotourism with social, religious and environmental functions; evaluation and control by making continuous quality improvement efforts. The internal potential includes land ownership status so that managers are free to express ideas in development; management competence $n$ the form of knowledge and experience in managing tourism objects; and extended family support to management. Its external potential includes positive responses from tourists who get pleasure and comfort after visiting the place; support from the surrounding community; and the influence of social media especially in promotion. 
Internal constraints include limited financial capital because everything comes from the manager's personal funds; human resources especially the ability of workers in language and tourism services; and then unstructured and systematic management. Externally, the constraints include government regulations especially in terms of taxes and tariffs, relationships with traditional institutions and local village government which has not been agreed; as well as uncertain sources of income.

\section{REFERENCES}

Ace, Cok. 2015. Taksu Dibalik Pariwisata Bali. Denpasar: Percetakan Bali.

Arida, I Nyoman Sukma. 2017. Ekowisata: Pengembangan, Partisipasi Lokal, dan Tantangan Ekowisata. Denpasar: Cakra Press.

Epler Wood, M. 1999. "The Ecotourism Society'-an international NGO commited to sustainable development" in Tourism Recreation Research, Vol. 24, 1999, pp. 119-123.

Mc.Millan, David W and David Chavis. 1986. "Sense of Community: A Definition and Theory", in Journal of Communicaty Psychology, 14 (1), pp. 6 -23.

Miles, Mathew B. dan Huberman A. 1992. Analisis Data Kualitatif. Jakarta: Universitas Indonesia.

Moleong, Lexy J. 1993. Metodologi Penelitian Kualitatif. Bandung/Jakarta: Yayasan Obor Indonesia.

Peraturan Menteri Dalam Negeri Nomor 33 Tahun 2009 tentang Pedoman Pengembangan Ekowisata di Daerah.

Picard, Michel. 1997. Bali: Cultural Tourism and Touristic Culture. Singapore: Archipelago Press . 2006. Bali: Pariwisata Budaya dan Budaya Pariwisata (Penerjemah: Jean Couteu dan Warih Wisatsana). Jakarta: Kepustakaan Populer Gramedia.

Siagian, Sondang P. 2000. Manajemen Strategis. Jakarta: Bumi Aksara.
Sztompka, Piotr. 2004. Sosiologi Perubahan Sosial. Jakarta: Prenada Media.

Umar, Husein. 2010. Desain Penelitian Manajemen Strategik: Cara Mudah Meneliti Masalah-Masalah Manajemen Strategik untuk Skripsi, Tesis, dan Praktis Bisnis. Jakarta: PT RajaGrafido Persada.

Wheleen, Thomas L. and J. David Hunger. 2003. Strategic Management and Business 003Policy Toward Global Sustanibility. 13th Edition. USA: Pearson Education Inc. 